\title{
The impact of conflict and security budget for conflict management on gross domestic product in Nigeria
}

\author{
Ijeoma, N. B. \\ Department of Accountancy, Nnamdi Azikiwe University, Awka-Nigeria
}

Email address:

amaro4baya@yahoo.com

\section{To cite this article:}

Ijeoma, N. B.. The Impact of Conflict and Security Budget for Conflict Management on Gross Domestic Product in Nigeria. International Journal of Business and Economics Research. Vol. 3, No. 1, 2014, pp. 29-36. doi: 10.11648/j.ijber.20140301.14

\begin{abstract}
This study assessed the impact of conflict and security budget for conflict management on gross domestic product in Nigeria. Secondary source of data gathered from published articles on peace and development, internet reports on conflicts, publications from the Federal Ministry of Finance and National Bureau of Statistics from 2000-2012 was employed. The statistical tools used to analyze the data include regression analysis, correlation analysis and the line graph analysis. From the result of the analysis it was observed that incidence of conflict and gross domestic product has a positive correlation with an association measure of $68 \%$. Also, it was found that incidence of conflict contributed significantly to the behavior of gross domestic product and it was found that increase on incidence of conflict reduces the gross domestic product of Nigeria. The existence of a strong positive correlation was found between security budget for conflict management and gross domestic product with an association measure of $72.7 \%$. It was equally found that security budget for conflict management contributed significantly to the behavior of gross domestic product in Nigeria. The result explained further that as security budget increases gross domestic product increases. This result implies that as more money is been budgeted for conflict management, gross domestic product increases in turn; since there will be less of conflict and greater room for economic development.
\end{abstract}

Keywords: Conflict, Gross Domestic Product, Security Budget, Economic Development, Conflict management

\section{Introduction}

Conflicts in developing countries like Nigeria, Ghana, Sudan and Kenya can be viewed as post colonial phenomenon and the largest cause of refugee flow. About $40 \%$ of countries in Africa have been in conflict in addition to the fact that this region is said to be hosting the second (after Asia) largest number of refugees. There is reason to believe that both of these factors could explain differences in per capita gross domestic product (GDP) growth between nations in Africa and their Asian and Latin American counterparts. Clearly, Africa, especially sub-Saharan Africa has been underperforming compared to other developing regions. It cannot be denied that peace is a prerequisite for global and national sustainability while conflict in the other hand has dampening effect on economic activity. A lot of economic benefits are associated with peace which, it then becomes apparent that involvements in peace carry with them substantial long-term benefits. Peace creates the optimum environment in which activities that contribute to human growth take place. When there is peace, it is easier for workers to produce, entrepreneurs and scientist to innovate businesses to sell and government to regulate. Conflict tend to affect food security by creating food shortages, which disrupt both upstream input markets and downstream output markets, thus deterring food production, commercialization and stock management. Depending on the location of the fights in a country, crops cannot be planted, weeded or harvested, decreasing dramatically the levels of agricultural production. In conflict situations, food producing regions experience seizure or destruction of food stock, livestock and other assets, interruption of marketed supplies of food not only in these regions but also in neighboring regions. These predatory activities diminish food availability and food access directly, because both militias and regular armies in the field tend to subsist by extorting the unarmed populations for food and any other productive resources. Any food that the militias and armies cannot use immediately in the contested areas will be destroyed to prevent their adversaries from accessing it. An example is in Ivory Coast where farming fared poorly during the months following October 2002, when government and rebel forces engaged in combat. Cocoa and coffee farmers fled their holdings because of rebels' threats, and cotton 
farmers in the North were short of income owing to their failure to transport their product to the port of Abidjan [1]. Countries of Africa, particularly those in Sub-Saharan Africa are a volatile mix of insecurity and conflict. The problem of conflict and insecurity is destabilizing the continent's peace process. It is right to argue that no continent that is bedeviled with the problem of peace and stability in its societal milieus could progress. Thus, the dire need for peace in the African countries is a matter that calls for great and urgent concern. Territorial disputes, armed conflict, civil wars, violence and the collapse of governments and ultimately the state have come to represent the greatest challenges to peace, security and stability. On the African continent, these threats have been much more pronounced and indeed have taken on a scale, intensity and frequency that have defied even the imagination of the greatest science fiction. Contributing on the devastating effect of conflict on most African countries, [2], discloses that the costs of conflicts in Africa in terms of loss of human life and property, and the destruction of social infrastructure are enormous. Hundreds of thousands of people have been killed in many of the countries in which the conflicts occur. Many others have also suffered and continue to suffer untold psychological trauma associated with conflicts. It was observed that once conflicts occur, scarce resources are inevitably diverted to the purchase of military equipment at the expense of socio-economic development. Speaking on the negative impact of conflict on education attainment, [3], found that from 1992 to 1998, exposure to the conflict, as measured by past damage to household dwellings, had a significant negative effect on enrolment of girls of ages 12-15 in schools. Girls who were of school age during the conflict and lived in conflict affected regions were $13 \%$ less likely to complete mandatory schooling compared to girls who had the opportunity to complete their schooling before the conflict started, and 7\% less likely to complete school than girls of the same age group who lived in regions relatively unaffected by conflict. Countries suffer from many different consequences of civil war and conflict. Conflict claims casualties in many different ways: civilians and sometimes soldiers are killed in combat, people die because there is a higher prevalence of preventable communicable diseases, shortage or unavailability of food; in fact, during wars people are killed due to increased violent crime. Post-war economies are predominantly in a worse shape than before the war and far from bringing an improvement to the political system, in general post-war societies are less democratic [4]. Violent conflicts affect economic outcomes mainly through the destruction of human and physical capital; shifts in public spending and private investment, as well as the disruption of economic activities and social life. The specific violent impacts depend on each conflict's singular characteristics: it is not just the type of conflict, but also its intensity, duration, and geographical spread that shapes its economic consequences. Also, it is expected that violent conflicts affect individual economic sectors differently, given differing characteristics [5]. As established in this present study so far that the effect of conflict on economic development of a country cannot be overemphasized. Also, the effect of conflict in one country can mare the trade link of another country. This is because war seems to frighten and drive investors away rather than attract them to a particular region. It is not only investors who are discouraged from these regions; even inter-state trade reduces in times of conflict. This is exacerbated by the dependence of some African countries, for example, on others for a major part of their trade (imports and exports), a case which applies especially to countries that do not have access to the sea (land locked countries). A country whose import and export is carried out by another country in conflict is at a greater risk especially if there are either no other options, or such other options are more expensive. The war in Mozambique doubled Malawi's international transport costs and triggered an economic decline. Similarly, the war in the Democratic Republic of Congo closed the river route to the sea for the landlocked Central African Republic [6]. [7], argued that economic growth and political stability are deeply interconnected. This is because political instability is believed to have strong adverse effects on economic prosperity. War, in general, and civil war, in particular, is one of the main causes of human suffering and economic underdevelopment [8]. In addition to the human sacrifice and suffering caused by wars, wars have had a devastating effect on the economic performance of the countries involved. Within the affected country, civil war evidently reduces GDP and accentuates poverty ([9], [10]). [11], asserted that conflicts and poverty are inextricably linked since conflicts lead to destruction of capital, displacement of people and increased insecurity, creating a vicious circle between conflicts and poverty. Nigeria is a country that relies on a single-commodity (oil) for export. Such countries are known to be vulnerable to conflict, price shocks in the world market, economic mismanagement and corruption. By not developing their varied mineral resources and diversifying export commodities, those countries make themselves vulnerable to conflict. When conflict erupts, it does not only sweep away decades of painstaking developmental efforts but also creates economic, social, political and regional costs and consequences that live on for decades. [12], believes that if a conflict can be anticipated, it can be prevented at least part of the time, with the aid of preventive diplomacy. [13], explained that the most obvious cost of conflict could be the disruption of economic activities. This is because it drastically reduces the per capita taxable capacity of the economy. Since businesses are more likely to wind up because of distortions, people flee and seek refuge in other countries or end up crowded in relatively safe areas of the conflicting country. Infrastructures are consequently destroyed leading to retarded economic growth. This concurs with the present case of northern Nigeria where the Boko Haram insurgency has caused a lot of people to flee to other parts of the country and this in turn is expected to reduce drastically economic activities in the 
northern region of the country. Also, the crises in Niger-Delta region of Nigeria has brought about some negative impacts on oil and economic activities and generally on governance. It has both economic impact and security impact. The activities of the Movement for Emancipation of Niger Delta (MEND) has varied from intensified attacks on oil platforms and pumping stations, to killing of soldiers to kidnapping foreign oil workers and set off car bombings. Heightened feelings of insecurities were created in the minds of people. Supporting the above [14], rightly pointed out that war leads to the diversion of public expenditure away from output enhancing activities. He continued to show that the most obvious way in which civil war damages the economy is through the destruction of some resources. For example, part of the labor force is killed or maimed and bridges are blown up. Finally, in response to the deterioration in the economic environment, private agents will engage in portfolio substitution; that is, shifting their assets out of the country. However, the question this study seeks to address is; 1 . Does incidence of conflict have impact on gross domestic product (GDP) in Nigeria and 2. Does security budget for conflict management have significant contribution on gross domestic product (GDP) in Nigeria? Hence, this study aims at determining the impact of conflict and security budget for conflict management on gross domestic product (GDP) in Nigeria.

\subsection{Literature Review}

[15], noted that in the face of present crises in Africa, the flaws underlying both modernization and democratization theories and the theory of colonialism are being exposed. The long held notion that modernity would result in smooth transition from authoritarian system to democratic system, with gradual elimination of conflict has failed woefully in Africa. [16], explained that historically, when youths are not engaged in meaningful work and are lacking the basic necessities, they bring attention to their plight by engaging in destructive behavior, this underscores the importance of Human Needs Theory. This result implies that when youths cannot bear their poverty (particularly lack of basic needs), caused or worsened by political corruption of most African leaders (who appear to be above the law or the law themselves) anymore, they react by engaging in conflict, with its negative effects, which stunt development. The case of youths in the Niger-Delta conflict in Nigeria is a good example, where the youths committed lots of atrocities, including the kidnapping of UK expatriates [17]. [18], argued that corruption, particularly political corruption directly undermines democracy and governance by destroying the trust relationship between the people and the state. An indispensable obligation of the state is to provide the basic needs of its people and also to ensure the safety of its citizens. When the state fails to fulfill this obligation, or provides for some groups, but not for others, or worse when the leaders are corrupt, the people effectively reclaim their right to use force (conflict) in the resolution of disputes, often with disastrous consequences, such as a rise in crime and stunted development. He concluded that Political Corruption causes or worsens Poverty which often leads to an increase in Conflict, and in turn leads to the stunting of Development. Also, he strongly argued that political corruption is the major and most persuasive causal factor and the human needs theory most relevant to resolving conflict in Africa. [19], reporting on the impact of conflict on food shortage through landmines. They noted that due to landmines, agricultural lands become inaccessible for years, harvests are destroyed and fields cannot be cultivated. Rural populations that depend on these fields for food are prevented from farming, therefore creating a breech in agricultural and food production. [20], found out that each percentage point off the growth rate of per capita income raises the risk of conflict by around one percentage point. He observed that in urban areas, wars are more likely to last longer and to be more deadly. Also, conflicts are more likely to arise in countries with fast growing population. He found that the level of ethnic fractionalization equally contributes to the risk of conflict. Ethnic fractionalization is measured by the ethno-linguistic fractionalization index, which measures the probability that two randomly selected individuals from a given country do not speak the same language. [21], explained that improving trade links depends highly on several factors, such as language, currency, transportation and, most importantly, on the political stability of neighboring countries. Crises in the neighboring countries can impose heavy financial transaction costs on trade, as shown by the price paid by Malawi and Zimbabwe after the civil war in Mozambique. Conflict spills over into neighboring countries does not come only in the form of refugees but also in the form of disruption of trade links and infrastructure and in the worsening of Africa's image. Politically unstable neighbors' will not only make trading impossible, but they will also serve as a source of burden, through the 'production of refugees', to its neighbors. On the other hand, it is expected that the more borders a country in conflict has, the better it is for its citizens who will have more flight options, and also the lesser the burden on one particular country. [22], reported that there is a new wave of empirical evidence on the effects of civil wars on neighboring countries; civil wars are not only devastating for the countries in which they are fought, but they also generate international spill over. They found that civil war substantially reduces the growth in both the war torn country and its neighbors' growth. This reduction can be attributed to multiple factors such as the disruption to trade, heightened risk perception by investors, a reduction of input supply and resources spent on assistance to refugees. Interestingly, it has been argued by some researchers that once a war has ended countries face a very high risk of recurrent conflict. Empirically, [9], estimated that there is a 50 percent risk of a conflict re-starting within five years of a settlement. In other words, once a country has had a civil war it is likely to have further conflict, so that, although peace is an improvement, risk levels do not return to their pre-conflict level. Consequently, even in peace time, 
people may still wish to move assets abroad. Therefore, countries coming out of conflict are typically in need of both financial resources and policy advice. Their societies are often extremely fragile and so it is important that the response of the international development community should be as appropriate as possible [23]. [24], argued that domestic social conflicts are major keys to understanding why growth rates lack persistence and why so many countries have experienced a growth collapse after the mid-1970s. Econometric evidence showed that countries that experienced the sharpest drops in growth after 1975 were those with divided societies (as measured by indicators of inequality and ethnic fragmentation) and with weak institutions of conflict management which was represented by indicators of the quality of governmental institutions, rule of law, democratic rights, and social safety nets. [25], showed that, compared to the average recession, countries that are associated with civil wars are ten percentage points deeper and last for ten more months. They also showed that economic contractions are not always followed by offsetting fast recoveries and adverse shocks may lead to absolute divergence and lower long-run growth. [26], also provides rich analysis on the effect of war on changes in the level and growth of GDP. They observed that civil war and genocide in the 1990-2000 periods in Rwanda caused convergence between provinces following the conflict shocks: previously richer provinces in the east and in the north of the country experienced lower, even negative, economic growth compared to the poorer western and southern provinces. This has in turn affected significantly the dynamics of household poverty in Rwanda in the same period. Speaking on the contributions of militarization on incidence of conflict in Africa, [27], argues that in associating militarization and conflict, caution needs to be taken because rather than the proliferation of arms in the society, it is the welfare-reducing effects of militarization that causes violence. Besides, when it is appreciated that developed countries with more sophisticated arms than Africa are not in conflict like the later, militarization as an explanation becomes weak. [8], observed that the greater part of the human costs of war does not result directly from battle deaths and injuries, but rather indirectly from the loss of livelihoods caused by the dislocation of the economy and society. Another strong theoretical argument underlying the relationship between conflict and growth is that during civil war, governments increase their military expenditure and this directly reduces economic growth. Government military spending increases during and immediately after war. A study by [28], stated that during civil war military expenditure rises as a percentage of GDP from $2.8 \%$ to $5.0 \%$. However, once the war has ended, military expenditure does not return to its former level. The average country during the first decade post-conflict spent $4.5 \%$ of GDP on the military. The increase in government military spending is part of the diversion of resources into violence but also harmful to growth because the resources controlled by rebel groups are also a diversion from productive activities. These diversions might be significant, and they increase with the duration of the conflict. [29], in their study provided a global panel data set of battle deaths. They define battle deaths as deaths due to military operations; this includes military as well as civilian fatalities. However, as they point out battle deaths are only part of the total war deaths. In addition to soldiers and civilians being killed in battle there are non-battle deaths which comprise of an increase in one-sided violence, an increase in crime and unorganized violence and in an increase in non-violent mortality (diseases). Examining the impact of the civil wars in Angola and Mozambique on children, [30], showed that the use of child soldiers was part of the warfare strategy. Children were either recruited by force or they joined because they sought protection or revenge. He noted that in Mozambique the rebel forces, RENAMO, used a minimum of 10,000 child soldiers, some as young as six or seven years of age. In 1994, 27 percent of the soldiers presenting themselves for demobilization were observed to be under the age of 18. In Angola a considerable proportion of the country's children took part in combat, about seven percent of all Angolan children had fired at someone. Children were thus victims and perpetrators of violence. Also, due to sexual violence or exchange of intercourse, generated during conflict, girls often have babies of their own. This makes it more difficult for girls to catch up on education and job training. There is also a high prevalence of sexually transmitted diseases which require treatment. Furthermore, due to their conflict time sexual experiences, girls are often regarded as 'second hand' and thus vulnerable to further abuse since it is more difficult for them to find husbands and have an ordinary family life. The study by [31], considered the impact of post-conflict aid in a theoretical framework and suggested improving the sequencing of aid flows. They noted that humanitarian help has the greatest welfare impact directly after the war but should be phased out in order to avoid counterproductive effects on economic growth and development. Reconstruction aid should be focused on the infrastructure rehabilitation of the tradable goods sector in order to avoid Dutch Disease effects.

\section{Material and Methodology}

\subsection{Data Collection}

Second-hand or secondary source of data gathered from published articles on peace and development, internet reports on conflicts, publications from the Federal Ministry of Finance and National Bureau of Statistics from 2000-2012 was employed in this study. Data obtained includes GDP, Incident of conflict and Security budget from 2000-2012.

\subsection{Regression Analysis}

Regression Analysis was used to determine the contributions of the explanatory variable "Gross Domestic Product (GDP)" on the dependent variable Incidence of 
Conflict. Regression analysis explains how one variable is related to another by providing an equation that enables the researcher to estimate the unknown value of a dependent variable using the unknown values of an independent variable [32]. Multiple regression analysis is a statistical technique that can be used to analyze the relationship between a single dependent (criterion) variable and several independent (predictor) variables [33].

The regression test statistic linear model parameters is given by

$$
y=\beta_{0}+\beta_{1} x_{1}+\beta_{2} x_{2}+\cdots+\beta_{n} x_{n}+\varepsilon_{n}
$$

The matrix form of equation (1) is expressed as

$$
\begin{array}{r}
y=X \beta+\varepsilon \\
\hat{\beta}=\left(X^{\prime} X\right)^{-1} X^{\prime} y
\end{array}
$$

Where, the y represents the dependent variable for the present study which is Incidence of Conflict and the explanatory or independent variable parameter $\left(\beta_{1}\right)$, represents the coefficient of the variable Gross Domestic
Product (GDP). Also, $\beta_{0}$ represents the parameter of the regression model constant and $\mathcal{E}$ represents the error or random effect of the model. The test of hypothesis for the present study is stated as given;

$\mathrm{H}_{01}$ : There is no significant impact of incidence of conflict on gross domestic product (GDP) in Nigeria

$\mathrm{H}_{11}$ : There is significant impact of incidence of conflict on gross domestic product (GDP) in Nigeria

$\mathrm{H}_{02}$ : There is no significant contribution of security budget for conflict management on gross domestic product (GDP) in Nigeria

$\mathrm{H}_{12}$ : There is significant contribution of security budget for conflict management on gross domestic product (GDP) in Nigeria

Decision Rule: The decision rule is reject the null hypothesis when the P-value is less or equal to the $\alpha=0.05$, otherwise, accept the null hypothesis.

\section{Analysis and Result}

\subsection{Regression of Impact of Incidence of Conflict on GDP}

Table 1. Model Summary

\begin{tabular}{ccccc}
\hline Model & R & R Square & Adjusted R Square & Std. Error of the Estimate \\
\hline 1 & $.680^{\mathrm{a}}$ & .463 & .414 & 11137.42995 \\
\hline
\end{tabular}

a. Predictors: (Constant), Incidence of Conflict

Table 2. $A N O V A^{b}$

\begin{tabular}{ccccc}
\hline \multicolumn{1}{c}{ Model } & Sum of Squares & df & Mean Square & Sig. \\
\hline & Regression & $1.176 \mathrm{E} 9$ & 1 & $1.176 \mathrm{E} 9$ \\
1 & Residual & $1.364 \mathrm{E} 9$ & 11 & $1.240 \mathrm{E} 8$ \\
& Total & $2.541 \mathrm{E} 9$ & 12 & \\
\hline
\end{tabular}

a. Predictors: (Constant), Incidence of Conflict

\begin{tabular}{|c|c|c|c|c|c|c|}
\hline & \multirow{2}{*}{ Model } & \multicolumn{2}{|c|}{ Unstandardized Coefficients } & \multirow{2}{*}{$\begin{array}{c}\text { Standardized Coefficients } \\
\text { Beta }\end{array}$} & \multirow{2}{*}{$\mathbf{t}$} & \multirow{2}{*}{ Sig. } \\
\hline & & B & Std. Error & & & \\
\hline \multirow{2}{*}{1} & (Constant) & 7791.334 & 5231.051 & & 1.489 & .164 \\
\hline & Incidence of Conflict & 2600.136 & 844.326 & .680 & 3.080 & .010 \\
\hline
\end{tabular}

b. Dependent Variable: GDP

Table 3. Coefficients ${ }^{a}$

a. Dependent Variable: GDP

\subsection{Regression of the contribution of Security Budget on GDP}

Table 4. Model Summary

\begin{tabular}{ccccc}
\hline Model & R & R Square & Adjusted R Square & Std. Error of the Estimate \\
\hline 1 & $.727^{\mathrm{a}}$ & .528 & .485 & 10440.34112 \\
\hline
\end{tabular}

a. Predictors: (Constant), Security Budget 
Table 5. $A N O V A^{b}$

\begin{tabular}{ccccccc}
\hline & Model & Sum of Squares & df & Mean Square & F & Sig. \\
\hline \multirow{3}{*}{1} & Regression & $1.342 \mathrm{E} 9$ & 1 & $1.342 \mathrm{E} 9$ & 12.310 & $.005^{\mathrm{a}}$ \\
& Residual & $1.199 \mathrm{E} 9$ & 11 & $1.090 \mathrm{E} 8$ & & \\
& Total & $2.541 \mathrm{E} 9$ & 12 & & & \\
\hline
\end{tabular}

a. Predictors: (Constant), Security Budget

b. Dependent Variable: GDP

Table 6. Coefficients ${ }^{a}$

\begin{tabular}{|c|c|c|c|c|c|c|}
\hline & \multirow{2}{*}{ Model } & \multicolumn{2}{|c|}{ Unstandardized Coefficients } & \multirow{2}{*}{$\begin{array}{c}\begin{array}{c}\text { Standardized } \\
\text { Coefficients }\end{array} \\
\text { Beta } \\
\end{array}$} & \multirow[t]{2}{*}{ t } & \multirow[t]{2}{*}{ Sig. } \\
\hline & & B & Std. Error & & & \\
\hline \multirow{2}{*}{1} & (Constant) & 13805.839 & 3514.172 & & 3.929 & .002 \\
\hline & Security Budget & 39.324 & 11.208 & .727 & 3.509 & .005 \\
\hline
\end{tabular}

a. Dependent Variable: GDP

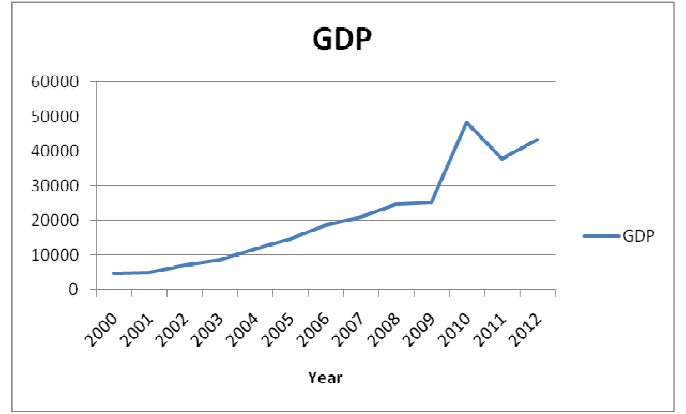

Figure 1. Annual Trend of GDP from year 2000-2012

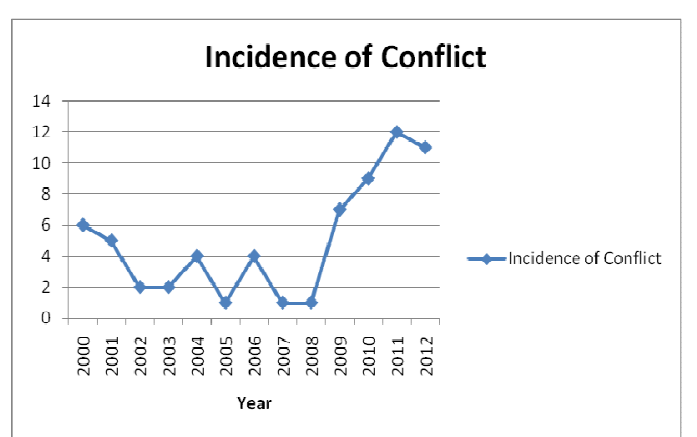

Figure 2. Annual Trend of Incidence of Conflict from year 2000-2012

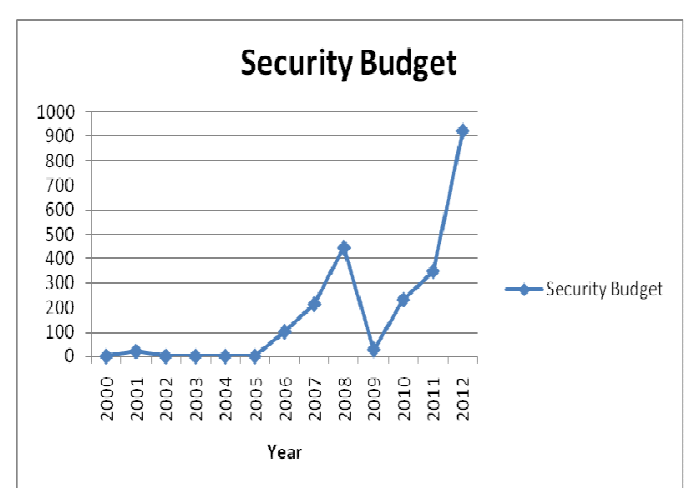

Figure 3. Annual Trend of Security Budget from year 2000-2012

\section{Discussion}

Table 1 (Model Summary) showed that incidence of Conflict can explain about $46.3 \%$ of the variation in GDP with an $\mathrm{R}$-square (coefficient of determination) $=0.463$. Also, the correlation or association between Incidence of Conflict and GDP is $68 \%$; this implies the presence of a positive correlation. Table 2 showed that the predictor variable incidence of conflict contributed significantly to the model with an F-ratio of 9.484 and a p-value of 0.01 which is less than $\alpha=0.05$ since the $\mathrm{p}$-value $=0.00<\alpha=0.05$. From Table 3 , it was found that incidence of Conflict contributed significantly to the model with a t-statistic $=3.080$ and a p-value of 0.01 which falls on the rejection region of the hypothesis assuming a $95 \%$ confidence Interval ( $\mathrm{P}$-value $=0.01<\alpha=0.05$ ). It was denoted that as Incidence of Conflict increases GDP increases.

Table 4 (Model Summary) showed that Security Budget was able to explain $52.8 \%$ of the variability in GDP with an $\mathrm{R}$-square (coefficient of determination) $=0.528$. Also, the correlation between Security Budget and GDP is $72.7 \%$; this result implies the existence of a strong positive correlation. From Table 5 it was observed that the predictor variable security budget contributed significantly to the model with an F-ratio of 12.31 and a p-value of 0.005 which is less than $\alpha=0.05$. From Table 6 , it was denoted that Security Budget contributed significantly to the model with a t-statistic $=$ 3,509 and a p-value of 0.005 which falls on the rejection region of the hypothesis assuming a 95\% confidence Interval ( $\mathrm{P}$-value $=0.005<\alpha=0.05$ ). It was observed that as Security Budget increases GDP increases.

From Figure 1 it was observed that GDP was highest in the year 2010; from Figure 2 it was denoted that the incidence of Conflict was most in the year 2011, equally there is no difference between the incidence of Conflict between year 2007 and 2008. From Figure 3 it was shown that there was a sharp fall on the Security Budget in year 2009 while security budget for year 2012 was observed to be the highest. 


\section{Conclusions}

This study assessed the impact of conflict and security budget for conflict management on gross domestic product in Nigeria. Also, the contribution of security budget on gross domestic product was equally evaluated. From the result of the analysis it was observed that incidence of conflict and gross domestic product had a positive correlation. It was found that incidence of conflict contributed significantly to the behavior of gross domestic product and that increase on incidence of conflict reduces the gross domestic product of Nigeria. This result is in line with argument by [34], where they stated that violent conflict hampers not only domestic exchange, but international trade flows as well. They observed that global trade flows are impeded to a greater extent by violent conflicts than by traditional tariff barriers. According to their estimates, bilateral trade flows for conflict-affected countries decline by up to 40 percent. In addition, the existence of a strong positive correlation was found between security budget and gross domestic product with an association measure of $72.7 \%$. It was equally found that security budget for conflict management contributed significantly to the behavior of gross domestic product in Nigeria. The result explained further that as security budget increases gross domestic product increases. This result implies that as more money is been budgeted for conflict management, gross domestic product increases in turn; since there will be less of conflict greater room for economic development [10].

\section{References}

[1] Taeb, M. (2004). Agriculture for Peace: Promoting Agricultural Development in Support of Peace. United Nations University-Institute of Advanced Studies, Japan, 2004.

http://www.ias.unu.edu/binaries/UNUIAS_AgforPeaceRepo rt.pdf.

[2] Wanyande, P. (1997). State Driven Conflict in the Greater Horn of Africa, Revised Paper Presented at the USAID Organized workshop on Conflict in the Great Horn of Africa May 21-23, Methodist House: Nairobi.

[3] Shemyakina, Olga. (2006). The Effect of Armed Conflict on Accumulation of Schooling: Results from Tajikistan. Households in Conflict Network Working Paper 12.

[4] Collier, P. and A. Hoeffler.(2007). Civil War, Chapter 23 in Handbook of Defense Economics T. Sandler and K. Hartley (eds), Volume 2, Elsevier 711-739.

[5] Blattman, C., Miguel, E. (2010). Civil War. Journal of Economic Literature 48 (1), 3-57.

[6] World Bank. (2003). Civil War and Development Policy. Policy Research Report, World Bank Group.

[7] Tangeras, T. P. and Lagerlöf, N. P. (2003). Ethnic Diversity and Civil War. Working paper No. 589, The Research Institute of Industrial Economics.

[8] Stewart F. and FitzGerald, V. (2001). Assessing the Economic Costs of War. War and Underdevelopment. 1. Oxford
University Press.

[9] Azam J. P., Colleir, P. and Hoeffler, A. (2001). International Policies on Civil Conflict: an economic perspective. Unpublished Working Paper.

[10] Abadie, A. and Gardeazabal, J. (2001). The economic costs of conflict: A case-control study for the Basque country. Working paper 8478 National Bureau of Economic Research.

[11] Elbadawi, I. (1999). Civil Wars and Poverty: the Role of External Interventions, Political Rights and Economic Growth. World Bank's Development Economic Research Group.

[12] Ross, M. (2002). Natural Resources and Civil War: An Overview with some policy options. Draft Report Prepared for conference on "The Governance of Natural Resources Revenue", World Bank and the Agence Francaise de Development, paris, December 2002.

[13] Collier, P. and Hoeffler A. (1998). On Economic Causes of Civil War. Oxford Economic Papers 50, 563-73.

[14] Collier, P. (1998). On the Economic Consequences of Civil War. Oxford Economic papers 51, 168-183.

[15] Irobi, G. (2005). Ethnic Conflict Management in Africa: A comparative Case Study of Nigeria and South Africa. Conflict Research Consortium: University of Colorado.

[16] Marke, D. (2007). Will Africa Ever Be Able To Replicate Successful Economies? December 16, 2007.

[17] Onyeiwu, S. (2004). On the Economic Determinants of Violent Conflict in Africa: Preliminary Evidence From Nigeria,Helsinki: Finland.

[18] Brian-Vincent I. (2009). The Relationship between Poverty, Conflict and Development. Journal of Sustainable Development, 2(1): 15-28.

[19] Messer, E., Cohen, M. J., and Jashinta D'Costa. (2000). Armed Conflict and Hunger. Hunger Notes. http://www.worldhunger.org/articles/fall2000/messer1.htm\#I ntroduction.

[20] Collier, P. and Hoeffler, A. (2000). Greed and Grievance in Civil War. World Bank Policy Research Paper 2355.

[21] Mkandawire T., Soludo, C. C., and Mkandawire, P. T. (2001). Our Continent, Our future, African Perspectives on Structural Adjustment. Africa World Press.

[22] Murdoch J. C. and Sandler, T. (2002). Economic Growth, Civil War and Spatial spillovers. Journal of Conflict Resolution, 46 (1): 91-110.

[23] Collier, P. and Hoeffler, A. (2002). On the Incidence of Civil War in Africa. Journal of Conflict Resolution, 46:13-28.

[24] Rodrik, D. (1999). Where Did All the Growth Go? External Shocks, Social Conflict and Growth Collapses. Journal of Economic Growth, 4(4):385-412.

[25] Cerra, Valerie and Sweta Chaman Saxena. (2008). Growth Dynamics: The Myth of Economic Recovery. American Economic Review, 98(1):439-57.

[26] Chen, Siyan, Norman Loayza and Marta Reynal-Querol. (2008). The Aftermath of Civil War. The World Bank Economic Review 22(1):63-85. 
[27] Omitoogun, W. (2001). Military Expenditure and Conflict in Africa. DPMN Bulletin, Vol. VIII, No. 1, July.

[28] Hoeffler, A. and Reynal-Querol, M. (2003). Measuring the Costs of Conflict. Unpublished Working Paper, Oxford.

[29] Lacina, B. and Gleditsch, N. P. (2005). Monitoring Trends in Global Combat: A New Dataset of Battle Deaths. European Journal of Population, 21(2-3): 145-166.

[30] Homvana, A. (2006). Child Soldiers in Africa. University of Pennsylvania Press: Philadelphia, PN.

[31] Demecas, D. G., McHugh, J. and Kosma, T. (2002). The
Economics of Post Conflict Aid, IMF Working Paper 02/198.

[32] Draper, N. R. and Smith, H. (1981). Applied Regression Analysis. $2^{\text {nd }}$ ed. John Wiley, New York.

[33] Motulsky, H. J. and Christopoulos, A. (2003). Fitting models to Biological Data using Linear and Nonlinear Regression. A practical guide to curve fitting. Graphpad Software Inc., San Diego CA,

[34] Blomberg, S. B., Hess, G.D. (2006). How Much Does Violence Tax Trade? The Review of Economics and Statistics, 88 (4), 599-612. 